\title{
2000年全国実態調査に基づく化学物質による住居室内空気污染の状況
}

\section{PRESENT STATUS OF THE INDOOR AIR CHEMICAL POLLUTION IN JAPANESE HOUSES BASED ON THE NATIONWIDE FIELD SURVEY IN 2000}

\author{
大澤元 毅*1, 池田耕一*2, 林 基哉*3, 桑 沢 保夫*4 \\ 真鍋 純*5, 中林由行*6 \\ Haruki OSAWA, Koichi IKEDA, Motoya HAYASHI, Yasuo KUWASAWA, \\ Jun MANABE and Yoshiyuki NAKABA YASHI
}

\begin{abstract}
The purpose of this research is to know the present status of the indoor air chemical pollution by VOCs in Japanese houses in 2000. The concentrations of formaldehyde, toluene, xylene and ethylbenzene were measured in five thousand houses, and the following results were obtained.

1) In $27.3 \%$ of surveyed houses, the indoor concentrations of formaldehyde exceeded the guideline established by the Ministry of health, labor and welfare of Japanese Government. And those of toluene, xylene and ethylbenzene were $12.3,0.013$ and $0 \%$ respectively.

2) The formaldehyde concentrations correlated well to the indoor temperatures.

3) The averages of the formaldehyde concentrations in houses according to the age of year after construction were analyzed, and the concentration in houses built after 1997 was lower than that in 1996, which showed the highest value.
\end{abstract}

Keywords : Indoor air quality, Field measurement, Formaldehyde, VOCS 室内空気質, 現場測定，ホルムアルデヒド，揮発性有機化合物

\section{1.はじめに}

我が国の住宅においては，耐久性等の性能や経済性を向上させる 目的で様々な化学物質を含む建材や，塗料・接着剤が一般的に利用 されている。一方，それらの化学物質による室内空気污染が要因と して考えられる居住者の健康被害が大きな全国的な関心を呼げ，そ の対策が急務となっている。

化学物質による空気污染問題発生の要因としては, 建材, 家具, 日用品等へ揮発性化学物質を使用する機会が増加していることの 他, 省エネルギー化と快適性改善をめざした住宅構造の断熱化と気 密化が省エネルギー基準の施行に伴って全国的に進行しつつあるこ と付やや，車の排気ガスなどによる外気の污染や騒音等による外部環 境の悪化，防犯のために窓を開放する条件が得られにくいなど，一 般的住宅における換気確保が次第に難しくなっていることなどが挙 げられている。しかし，特定の地域や建物構造等の条件に限定され ておらず，それらの影響程度は未だ明らかになっていない。
海外ではドイッ1),カナダ2), 米国3)等において数百軒単位の住宅を 対象とする調査報告が1980年代末から出されているが，わが国では， 熊谷らによる東北を中心とする50件の住宅における実態調查（平成 5 年 $)^{4), 5}$, 建築研究所による一連の実態調査 (平成 $9 \sim 11$ 年, 全国 149 戸(5)78)，山口らの木造独立住宅を对象とし居住者意識と室内濃度・ シェル夕一性能を関連づけた実態調査(平成11～12年，新潟県内 104 戸) ${ }^{9}$, 吉野らによる居住者の健康状況と関連づけた実態調查（平成 12 年, 宮城県内 22 户 $)^{10)}$, 朴らの保健所を通じて実施された全国調査

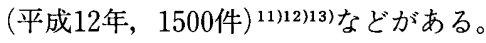

本報では，平成12年に全国規模で行った住宅室内のホルムアルデ ヒド・トルエン・キシレン・エチルベンゼンの濃度測定結果と，同 時に行ったアンケートによる建築材料・地域特性・建物工法・換気 設備に関する調查結果を用いて，ホルムアルデヒド室内濃度とそれ らとの関係について検討を加え，濃度平均值比較などによって，化 学物質による住宅の室内空気污染の奉態を多角的に示した。

\footnotetext{
${ }^{* 1}$ 国土交通省国土技術政策総合研究所住宅研究部 部長

*2 国立保健医療科学院建築衛生部 部長 $\cdot$ 工博

*3 宮城学院女子大学生活文化学科 教授. 工博

*4 国土交通省国土技術政策総合研究所 主任研究官・工博

*5 国土交通省住宅局住宅総合整備課 企画専門官

*6 綜建築研究所 代表取䋨役
}

Director, Department of Housing, National Institute for Land and Infrastructure Management, MLIT

Prof., Department of Architectural Hygiene and Housing, National Institute of Public Health, Ph. D.

Prof., Miyagigakuin Women's College, Dep. of Living and Cultural Science, Dr. Eng. Senior Researcher, Department of Housing, National Institute for Land and Infrastructure Management, MLIT, Dr. Eng.

Senior Deputy Director for Housing Development, Housing Development Division Housing Bureau, MLIT

President, Soken Associates 
表 1 アンケート調查項目

\begin{tabular}{|c|c|c|}
\hline \multicolumn{3}{|c|}{ 項目内容 } \\
\hline \multirow{4}{*}{ 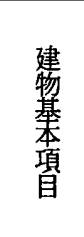 } & 住戸の建て方 & 一戸建て、共同建て(アパート、マンションなど) \\
\hline & 住宅の構造 & $\begin{array}{l}\text { 木造軸組工法、枠組壁工法、鉄骨系プレハブ造、木 } \\
\text { 啠系プンプ告、鉄筋コンクリート告 }\end{array}$ \\
\hline & 住宅の種類 & 持ち家、公営住宅、公団賃貸住宅、民間賃貸住宅 \\
\hline & 築年数 & $\begin{array}{l}\text { 新築後 } 1 \text { 年以内、新築後 } 2 \cdot 3 \text { 年、新築後 } 4 \cdot 5 \text { 年、 } \\
\text { 新築後 } 6 \sim 10 \text { 年、新築後 } 10 \text { 年超 }\end{array}$ \\
\hline \multicolumn{3}{|c|}{ 【アンケート項目一1】 項目内容 } \\
\hline 測 & 測定月 & 9 月、 10 月、 11 月、 12 月、 1 月、 2 月 \\
\hline \multirow{2}{*}{ 榼䞀 } & 天候 & 晴れ、くもり、雨 \\
\hline & 室温 & $10^{\circ} \mathrm{C}$ 末満、 $10 \sim 15^{\circ} \mathrm{C} 、 15 \sim 20^{\circ} \mathrm{C} 、 20 \sim 25^{\circ} \mathrm{C} 、 25^{\circ} \mathrm{C}$ 超 \\
\hline \multirow{3}{*}{  } & 部屋の名称 & 居間、寝室、子供室 \\
\hline & 部屋の階数 & 1 階、2階、3～5階、6～10 階、11階以上 \\
\hline & 測定室面積 & $\begin{array}{l}10 \mathrm{~m}^{2}\left(6 \text { 畳) 以下、 } \sim 13.2 \mathrm{~m}^{2}\left(8 \text { 盢)、 } \sim 16.5 \mathrm{~m}^{2}(10\right.\right. \\
\text { 鰛)、 } 19.8 \mathrm{~m}^{2}(12 \text { 盢) ….. }\end{array}$ \\
\hline \multirow{3}{*}{$\begin{array}{l}\text { 行測 } \\
\text { 定 } \\
\text { 部 } \\
\text { 至 }\end{array}$} & 床の仕上 & 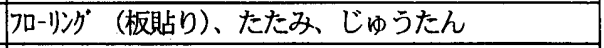 \\
\hline & 壁の仕上 & 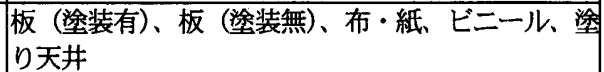 \\
\hline & 天井の仕上 & $\begin{array}{l}\text { 板 }(\text { 塗装有)、板 (塗装無)、布・紙、ビニール、湓 } \\
\text { り天井 }\end{array}$ \\
\hline \multicolumn{3}{|c|}{ 【アンケート項目一2】 } \\
\hline \multicolumn{3}{|c|}{ 項目内容 } \\
\hline \multirow{3}{*}{$\begin{array}{l}\text { 換 } \\
\text { 害 } \\
\text { 凑 }\end{array}$} & \begin{tabular}{|l} 
自動（24 時 \\
間）
\end{tabular} & 有（仵 \\
\hline & $\begin{array}{l}\text { その他の換気 } \\
\text { 装置 }\end{array}$ & 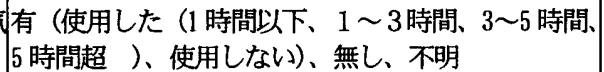 \\
\hline & 空開放 & $\begin{array}{l}\text { 開放した（1 時間以下、1 } 3 \text { 時間、 } 3 \sim 5 \text { 時間、超、時 )、開放しない } \\
\end{array}$ \\
\hline \multirow{4}{*}{ 告 } & |冷房機器 & \begin{tabular}{|l|} 
使用した (1 時間以下、1〜3 時間、 $3 \sim 5$ 時間、 $5 \sim 7$ \\
時間、7 7 時間時間超 )、使用しない
\end{tabular} \\
\hline & 暖房（エアコさ） & 侗上 \\
\hline & 暖房 $($ 자-ブ $)$ & 同上 \\
\hline & 暖房 (その他) & 同上 \\
\hline \multicolumn{2}{|c|}{ リフォームの有無 } & $\begin{array}{l}\text { リフォームした }(1 \text { 年以内、 } 2.3 \text { 年前: } 4.5 \text { 年 } \\
\text { 前、 } 6 \sim 10 \text { 年前、 } 10 \text { 年以上前)、しない }\end{array}$ \\
\hline \multicolumn{2}{|c|}{ 体調の変化 } & 無、有、不明 \\
\hline \multicolumn{2}{|l|}{ 地域 } & I 地域、I地域、III地域、IV地域、V地域、VI地域 \\
\hline
\end{tabular}

\section{2. 調査概要}

\section{1 調查対象}

調査は，全国の住宅における実態を把握することを目的にして， 調査対象を全国の住宅5000戸（全都道府県の住宅関連部局を通じて 募集した 3000 戸，インターネットで全国に公募した2000戸）を目標 として実施した。なお，新築住宅の最新の状況把握を重視し，公募 に際しては「原則として 1 年以内の新築」を条件に揭げたが，経年 変化に関する資料を得るため，築後 1 年超の住宅を約 $30 \%$ 含む。公 募は，当初，平成 12 年 8 月から 11 月末を締め切りとしたが，十分な 数の応募がなかったため，期限を数ヶ月延長して行った。

\section{2 使用サンプラーと分析}

実態調査はパッシブサンプラーを用いた濃度測定と，アンケート より構成される。一般的に蒸気拡散式 (パッシブ) サンプラーには, (1)取り扱いが簡単であること，(2)安価で広域大量調查に適している， (3)妨害ガスの影響を受けにくい，というメリットがある。

今回の実態調查では，ホルムアルデヒド, トルエン, キシレン,
表 2 調査件数と構成比率

調查件数と構成比率

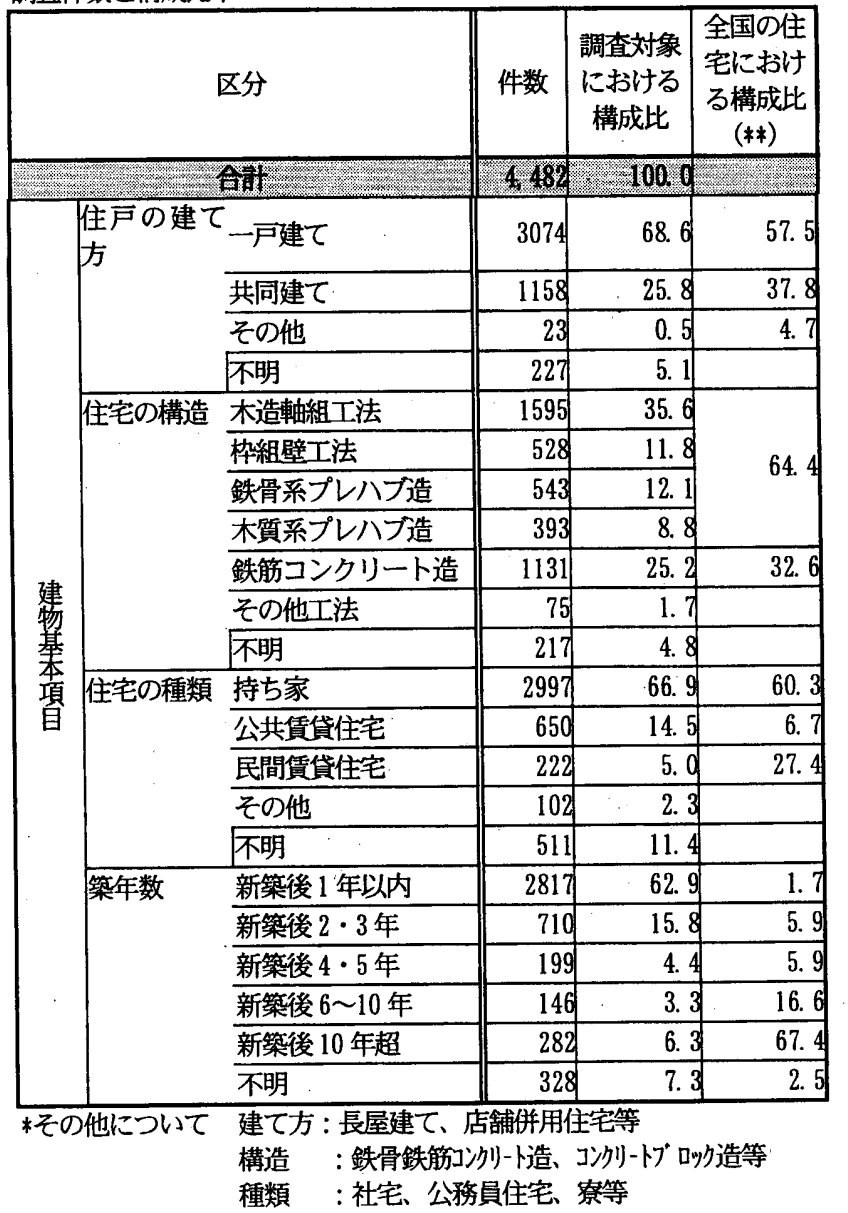

*椎宅·土地統計調查報告平成 10 年 全国編 総務庁統計局上り

エチルベンゼンの 4 種類の気中濃度を把握するため 2 種類のパッシ ブサンプラーを使用した。

ホルムアルデヒドの捕集には，アドバンスケミカル社製 F-50を， 残り 3 物質にはアドバンスケミカル社製 OV-9を用いた。分析は, ホルムアルデヒドについては高速液体クロマトグラフ法（HPLC 法)で行い, 残りの 3 物質はガスクロマトグラフ法により行われた。 なお測定温度による換算は， $24^{\circ} \mathrm{C} て ゙$ 測定されたものとして一律に 実施し, 濃度を表示した。これらの採取機器については精度の検証 実験が行われており，通常の测定環境における精密法による測定值 との誤差はいずれも20\%以内であることが確認されている14)

\section{3 調査方法}

調査对象住宅にパッシブサンプラーを送付して，机上（皿上）な ど床上 $1.2 \sim 1.5 \mathrm{~m}$ の高さに設置又はつり下げる等の方法で24時間 該当居室内に設置した後に密封してアンケートとともに返送するこ とを調査協力者に依頼した。また，パッシブサンプラーを設置した 部屋の空はなるべく開放しないで通常のように生活をすることを居 住者に依頼し，その間の状況はアンケートで確認した。測定日の室 内温度については午後 2 時〜 3 時の室温を 5 つの温度域 $\left(10^{\circ} \mathrm{C}\right.$ 末満, $10 \sim 15^{\circ} \mathrm{C}, 15 \sim 20^{\circ} \mathrm{C}, 20 \sim 25^{\circ} \mathrm{C}, 25^{\circ} \mathrm{C}$ 超) 加選択させている。

アンケート項目を表 1 に示す。大規模調査であるため, 調査協力 者の記入負担を減らしてアンケートの有効回答率を確保するために 質問数を絞り込むとともに，可能な限り選択式とした。 


\section{4 回収率について}

応募期限を延長したことによって，実際の测定時期は，2000年 9 月から2001年 3 月までとなった。配布数4909のうち，11月末日まで の回収数は $4482(91 \%)$ であり，このうち4368（89\%）が有効サン プル数として処理された。調查時期は, 10 月と 11 月が最も多く計 2800 サンプルで全体の約 $60 \%$ を占める。従って今回の調査の母集団は, 一部の寒冷地域を除くと, 暖冷房の必要性が低い中間期を中心とし たものであることに留意する必要がある。
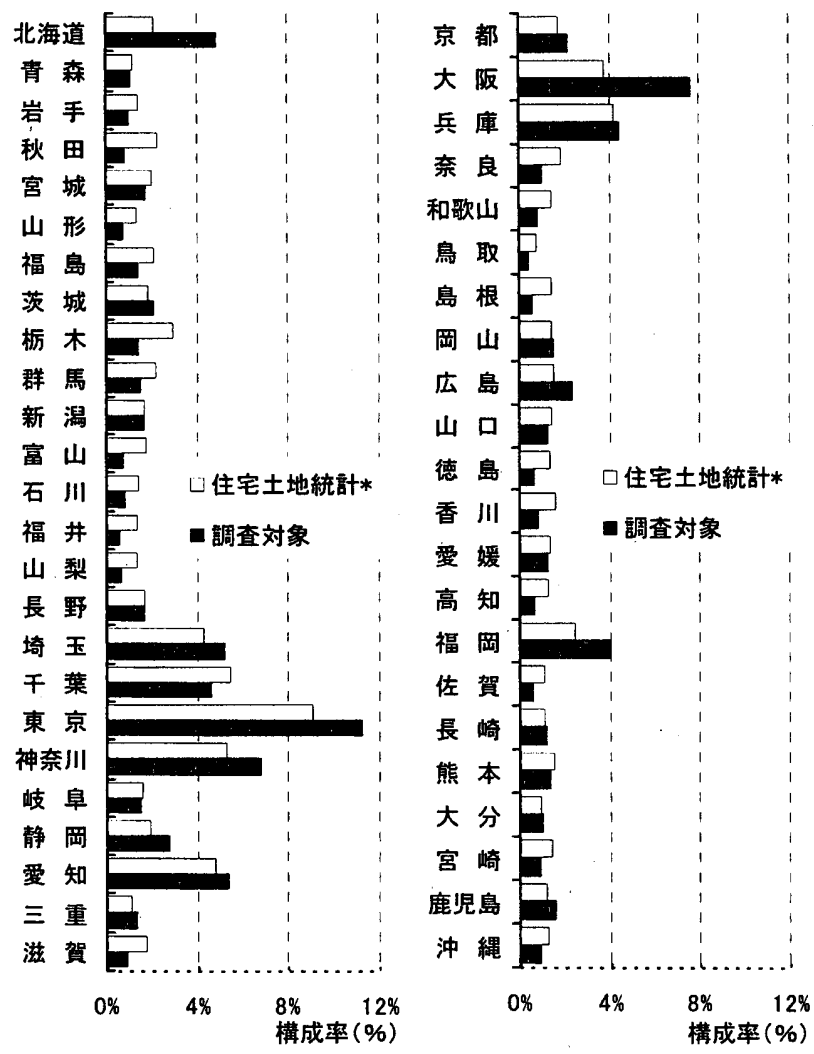

図 1 住宅数分布之調查対象住宅の全国分布 *住宅·土地統計調查報告平成 10 年 全国編 総務庁統計局上り

調查対象物件の構成は表 2 に示寸通りで， 1 年以内の物件は約 $63 \%$ となった。また, 対象住宅の建て方, 構造, 種類, 築年数等の 要因に関する構成も，新築比率が高いことを除けば，母集団の構成 はわが国の住宅全体像と類似した状況であった。

また図 1 に示すように，対象住宅数の地域分布についても東京都 が最も多いなど，住宅数の分布をほぼ表現している。

\section{3. 調査結果}

以下に今回の実態調查から得られた結果を示す。化学物質の平均 濃度, 対象住宅の属性別の濃度, アンケート項目とのクロス集計な どであるが，紙面の都合もあって主たる結果を拔粋した。

\subsection{4 物質の全平均濃度}

1）4476件のホルムアルデヒド濃度の分布を図 2 に示す。平均濃度 は0.071 ppm で，厚生労働省の指針值 $0.08 \mathrm{ppm}^{15)}$ を下回ったもの の，全体の $27.3 \%$ ( 1,224 件) が指針值を超えていた。最高濃度は $0.34 \mathrm{ppm}$ で指針值の約 4 倍であった。

2）トルエン濃度の分布を図 3 に示す。平均濃度は $0.038 \mathrm{ppm}$ で指

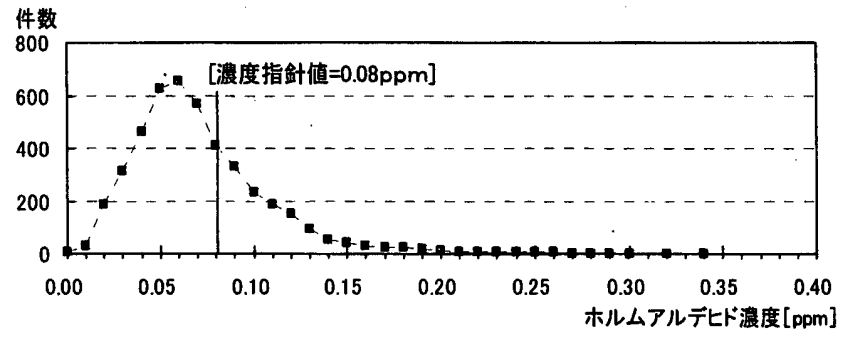

図 2 ホルムアルデヒド濃度の頻度分布

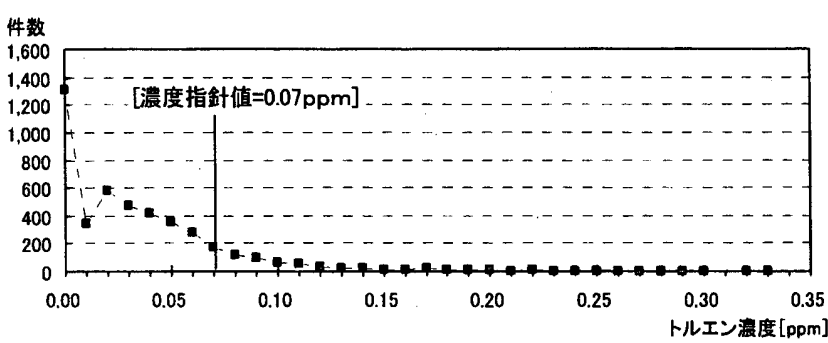

図 3 トルエン濃度の頻度分布

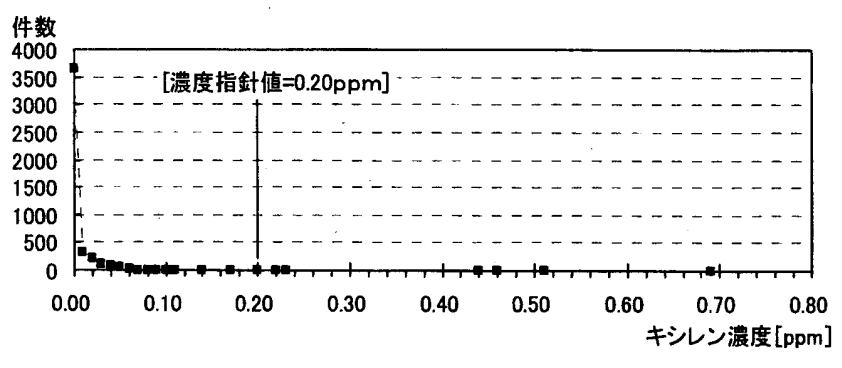

図 4 キシレン濃度の頻度分布

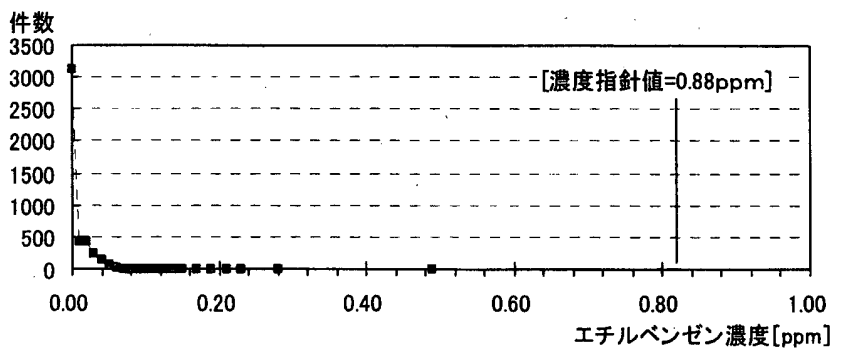

図 5 エチルベンゼン濃度の頻度分布

針值の $0.07 \mathrm{ppm}$ をかなり下回ったが，全体の $12.3 \%$ (552件) が指 針値を上回っていた。その最高濃度は $1.27 \mathrm{ppm}$ で指針值の約 17 倍 であり，指針值の10倍を超える高濃度な住宅（10件）の存在が特 徵的なことから今後, その原因究明が必要とされる。

3 ）キシレン濃度の分布を図 4 に示す。平均濃度は $0.005 \mathrm{ppm}$ で指 針值の $0.20 \mathrm{ppm}$ を大きく下回り，指針值を超えた住宅はわずかに $0.013 \%$ （6 件）である。最高濃度は0.69ppm で指針值の 3.5 倍で あった。

4 ）エチルベンゼン濃度の分布を図 5 に示す。平均濃度は $0.008 \mathrm{ppm}$ で指針值の $0.88 \mathrm{ppm}$ を大きく回り，全てのサンプルが指針值以 下であった。従って，その最高濃度も $0.49 \mathrm{ppm}$ と指針值より低 かった。 


\section{2 室内温度とホルムアルデヒド濃度}

アンケートに記入された申告に基づき，温度域別に集計したホル ムアルデヒド平均濃度を図 6 に示す。物理的測定によらないことか ら温度データの信頼性に限界はあるものの, 室温が高いほど平均濃 度も高くなるという傾向が明確に現れていた。同一の室における データではないが， $25^{\circ} \mathrm{C}$ 以上のグループ (567件) における平均濃度 が0.092ppm と指針值 $(0.08)$ を超えているのに対し， $10^{\circ} \mathrm{C}$ 未満のグ ループ (77件) では $0.049 \mathrm{ppm}$ と低く, 温度が $10^{\circ} \mathrm{C}$ 上がると平均濃度 は $40 \%$ あまり上昇するという結果を得た（ $\mathrm{p}<0.0001 ，$ 表 3$) 。$

ただし, 温度上昇に伴う濃度上昇の比率は, 井上の式备)の值より低 かった。これには，室温が高い場合には空を開放することで換気量 が増大するなどの生活行動の介在が要因として考えられる。なお， 図 6 中の高低線は, 上端が平均值に標準偏差を加えた值，下端が平 均値から標準偏差を引いた值を示している(以下, 図 $7 \sim 13,16 \sim 18$ も同様)。

\section{3 築後年数とホルムアルデヒド濃度}

築年数別にホルムアルデヒドの平均濃度を図 7 に示す。自然減衰 により室内濃度は経年とともに低下寸ることが予想されたが，本調 查では築後 $4 \sim 5$ 年の住宅における平均濃度が最も高く（指針値を 超える0.082ppm)，新筑はそれより低い（筑 1 年以内は $0.073 \mathrm{ppm}$ ) 水準となっていた。この時期は, 厚生省（現厚生労働省）がホルム アルデヒドの室内濃度指針值を公表した1997年（平成 9 年） 7 月， 住宅団体連合会が「住宅内の化学物質による室内空気質に関する指 針」を公表した1999年（平成11年） 3 月と概ね符合し，築後 $4 \sim 5$ 年の住宅はこの指針值公表以前の建設なのに対し，以後の住宅はこ れに対応して材料選択等に配慮が加わった結果との推測が可能であ る。なお，同図中に示す室温は，室温申告で選択された温度巾の中 間值を用いて平均を計算した結果である。築後年数が小さいほど室 内温度平均值が高い傾向があることを示している。

ホルムアルデヒド濃度に関するこの傾向が，室温に影響されてい ないかどうかを，温度域毎の築年数別平均濃度（図 8 ）で検討した が，いずれの温度域においても築 4 〜 年付近をピークとする山型 になっており，共通の現象であることが確かめられた。

\section{4 測定対象室の階数とホルムアルデヒド濃度}

一戸建て住宅における階数別平均濃度を，図 9 に示寸。上階にな るほど濃度が高くなる傾向が現れており，住宅の内部空間が階段な どでつながっているために，煙突効果による上昇気流によって下階

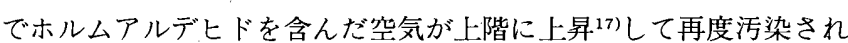
ること，2 階に濃度が高い個室（子供室）が多いことなどが原因と 考えられる。なお，一戸建て住宅の階別の䆓温平均值には，階数と の間に傾向が見出せなかった。同様に，共同住宅における階数別平 均濃度を図10に示す。この場合も上階になるほど濃度が高くなる傾 向を示したが，共同住宅の各住戸はフラット形式で，上下階間の気 流も無いことから戸建ての場合の仮説を当てはめることはできない。

建物階数と平均濃度との関係を整理したところ, 中層住宅 (83件) では0.063ppm，高層住宅 (185件) では0.074ppm，超高層住宅 (105 件)では $0.097 \mathrm{ppm}$ と，階数の高い建物はど濃度が高い関係が明らか になった。これらを住戸の階数別に集計すると, 濃度の高い超高層 住宅だけからなる上層階住戸の濃度が最も高くなり，中層住宅が混 在する低層階での濃度が最も低くなることが説明できる。

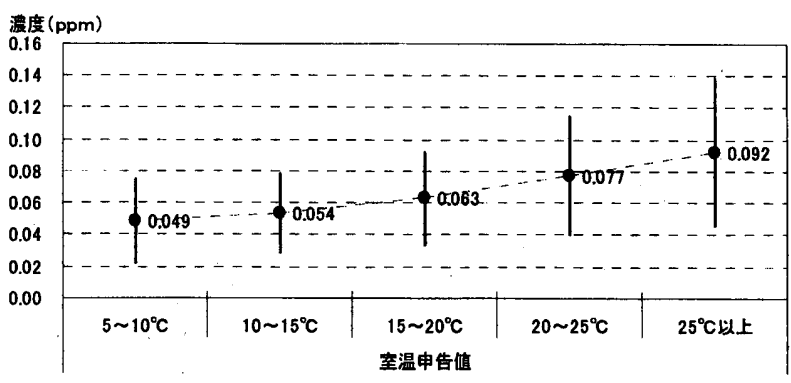

図 6 申告室温とホルムアルデヒド濃度

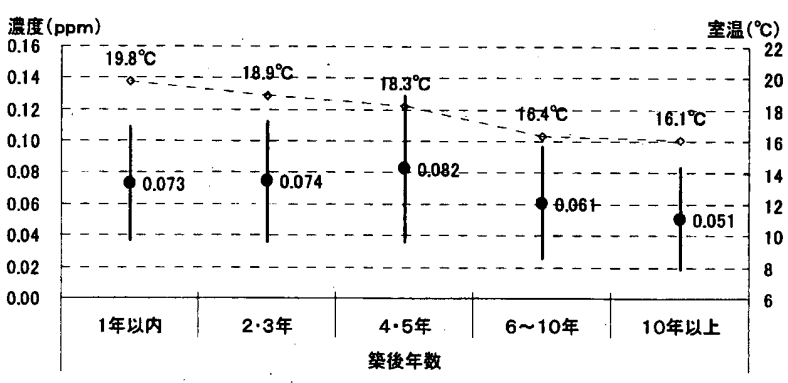

図 7 築後年数とホルムアルデヒ.ド濃度

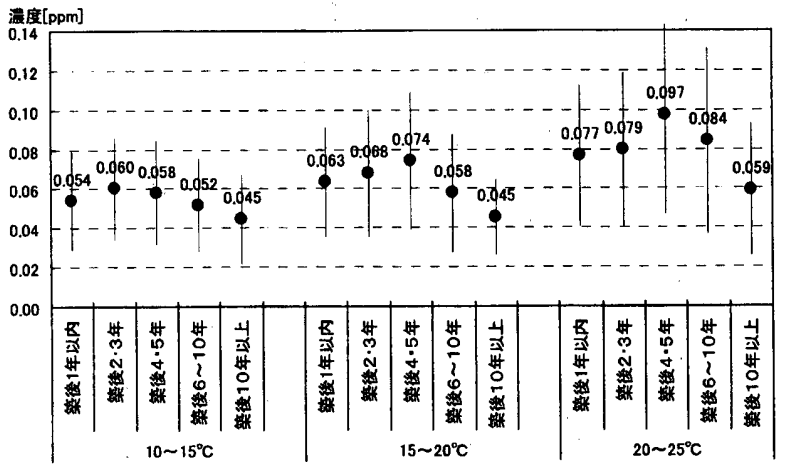

図 8 築後年数別申告室温別のホルムアルデヒド濃度



図 9 階数とホルムアルデヒド濃度（一戸建ての場合）

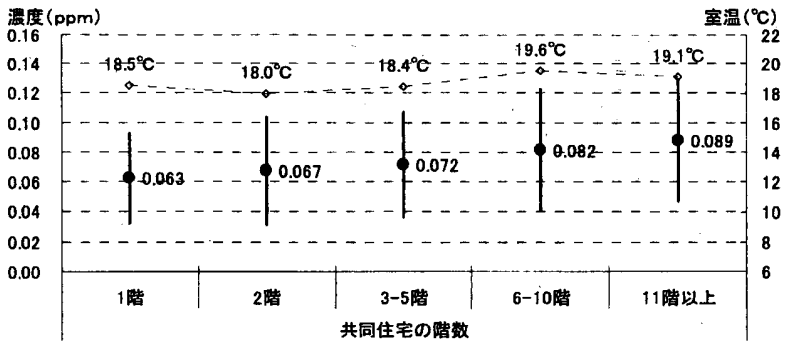

図10 階数とホルムアルデヒド濃度（共同建ての場合） 
なお，超高層建物で濃度が高い理由は明確ではなく今後の研究に まつ必要があるが, 気密性が高い上，風が強いため空を開けにくい ことが多い，企画設計施工の期間が長く内装材料の選定において新 しいホルムアルデヒド対策が十分に行われていないなどが理由とし て考えられる。

\section{5 換気とホルムアルデヒド濃度}

換気による濃度低減効果を見るために，24時間連続換気設備の有 無と運転状況とホルムアルデヒド濃度の関係を図11に示す。連続換 気設備無し（3212件）の濃度0.071ppm と, 有りで運転 (901件)の $0.071 \mathrm{ppm}$ に顕著な有意差は見られない $(\mathrm{p}=0.12)$ 。「有り」と答之 た住宅は一般に気密性の高い構造が多いと考之られるが，その中の 約14\%が連続換気設備を使用していない(停めてしまっている)。そ の「有り一運転」(901件) の平均濃度 $0.071 \mathrm{ppm}$ に対し，「有り一停 止」(159件)では $0.077 \mathrm{ppm}$ で, 仮に建物設計や換気性能に差がない と仮定すれば，連続換気設備の濃度低減効果は約 $10 \%$ 程度と見るこ とができる。このように 24 時間換気設備の効果は設計上の換気回数 増加から予測されるほど現れておらず, 換気設備設計或いはその運 転実態把握も含めて今後の調査課題である。

空の開放および開放時間と濃度との関係を見たのが図12である。 空を開放しない閉鎖の場合 (2951件)の0.074ppmに対して，開放時 間の多少にかかわらず，開放がなされた場合全て（1209件）を対象 に平均したホルムアルデヒド濃度は $0.066 \mathrm{ppm}$ となり，10\%程度の 差が見られた。窓の開放時間については，「 $3 \sim 5$ 時間」の濃度がや や高いが, 開放時間増加と共に濃度が低くなる傾向が見られた $(\mathrm{p}<$ 0.0001)。「 $3 \sim 5$ 時間」の濃度が上昇した原因としては，室温が高 めであることなどが考えられる。

\section{6 体調变化とホルムアルデヒド濃度の関係}

アンケートの「入居してから体調の変化がありましたか」という 問に，「ある」と答えた人は 651 件で，全体の $14.5 \%$ であった。医師 の診断を受けたかどうかは不明であるが，自由記入の症状欄による と, 頭痛など122件, 目の異常166件, 皮䖉の異常174件, 喉の異常 199 件の順に多くなっていた。なお，この項目は，居住者の申告による もので, 医師の診断によるものではないことに留意する必要がある。 ホルムアルデヒド濃度の測定結果との関係(図13)を見ると，「なし」 と答えた 3682 件のホルムアルデヒドの平均濃度が $0.071 \mathrm{ppm}$ である のに対し，「ある」の平均は $0.077 \mathrm{ppm}$ と $10 \%$ 弱高くなっていた。ホ ルムアルデヒドの濃度別に「体調変化有り」と答えた人の比率をプ ロットしたところ(図14)，0.12ppm 位までは発生率は15\%程度の横 這いであるが, $0.13 \mathrm{ppm}$ 程度から発生率が濃度とともに高くなる傾 向を示していた。図15に建て方別の体調変化発生率を示した。体調 変化有りと答えた住宅でのホルムアルデヒド平均濃度は, 一戸建て で0.077ppm, 共同建てで0.078ppm とほとんど変わらないにもかか わらず，共同建てにおける体調変化の発生率は戸建ての $11.5 \%$ に対 して約 2 倍の $21.6 \%$ となっていた。

\section{7 地域別のホルムアルデヒド濃度}

全都道府県からサンプルを得たことを利して地域別の分析を試み た。㘡16に，新省エネルギー基準の地域区分ごとの平均濃度を示す。 ホルムアルデヒド放散は温度の影響を強く受けることから，気温の 高い地域ほど濃度が高くなると予想したが, I 地域(北海道) が0.091 ppm と沖縄に次いで高くなるという結果になった。

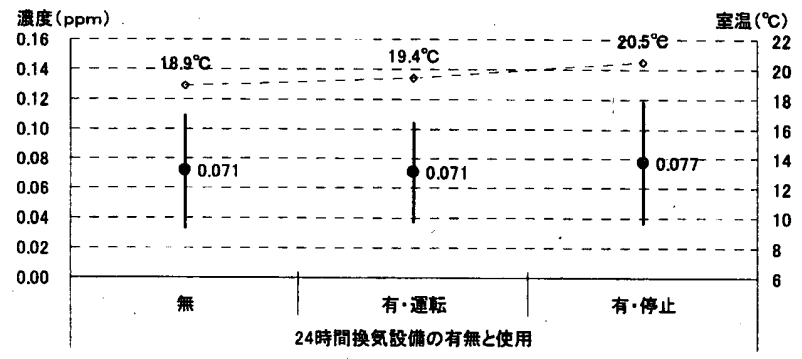

図1124時間連続換気設備の有無及び使用状況とホルムアルデヒド濃度

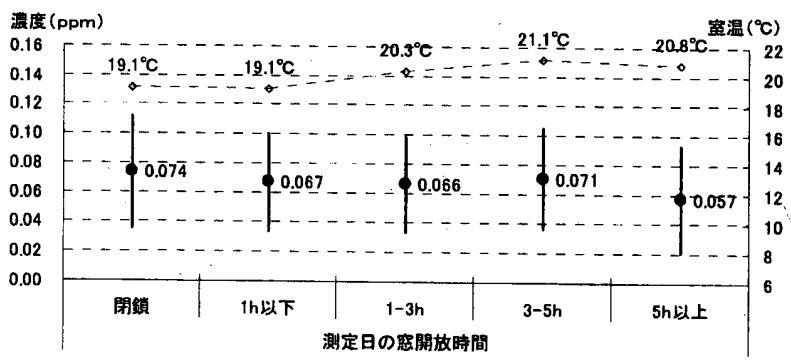

図12＼cjkstart窓の開放状況とホルムアルデヒド濃度

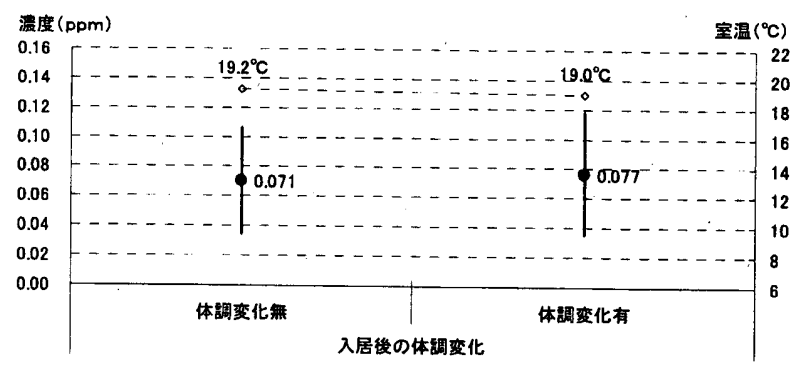

図13 体調変化の申告とホルムアルデヒド濃度

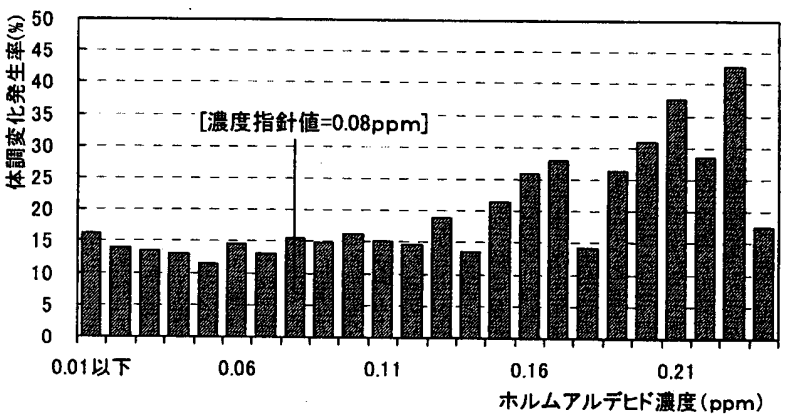

図14 ホルムアルデヒド濃度別の体調変化発生率

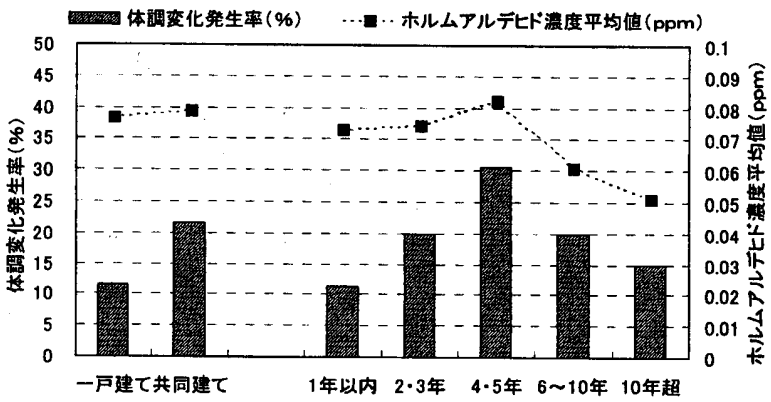

図15 建て方・築後年数別体調変化発生率とホルムアルデヒド濃度 
寒冷地ほど気密性の高い住宅が多いこと，暖房時の室内温度が高 いことなどが原因として考えられるが，さらに調査を継続する必要 がある。

\section{8 その他のアンケート項目との関係}

一戸建てと共同建てのホルムアルデヒド平均濃度は共に0.072 ppmで変わりはない。構造別に見ると，枠組壁工法がやや高く，鉄 骨系と木質系のプレハブがやや低かった。持ち家，公共賃貸，民間 貨貸の間に濃度の差はほとんどなかった。天候別では，雨の日の平 均濃度がやや高いという結果が出た.(図17, $\mathrm{p}<0.0033$ )。

一戸建て住宅における階数及び室用途別では，2 階の個室が高い 傾向が示された。用途別では，居間は階数に寄らずに低いのに対し て，子供室や寝室などの個室は，1階では低く 2 階では高い傾向を 示した。これは，1階の個室は居間に隣接して開放的に使用される 場合もあるためであると推定される(図18，p<0.0001）。

なお，以上の分析結果については，表 3 に示すように分散分析に よる平均值の差の検定を行い, $\mathrm{P}$ 值によって有意差を判定した。この 検討より，図11における24時間連続換気設備の有無及び使用状況に よる濃度比較において $\mathrm{p}$ 值が 0.11 を越えて有意差が無いこと，24時 間連続換気設備が有りの場合のみで運転と停止の濃度比較を行うと， $\mathrm{P}$ 值は0.0318で0.05未満となり有意差があることなどが示された。

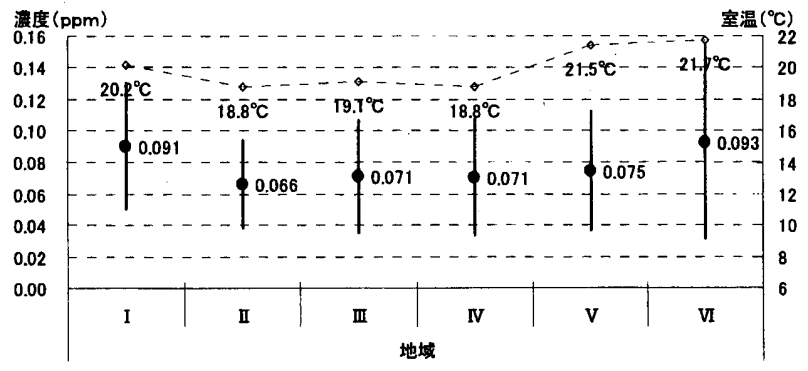

図16地域別のホルムアルデヒド濃度

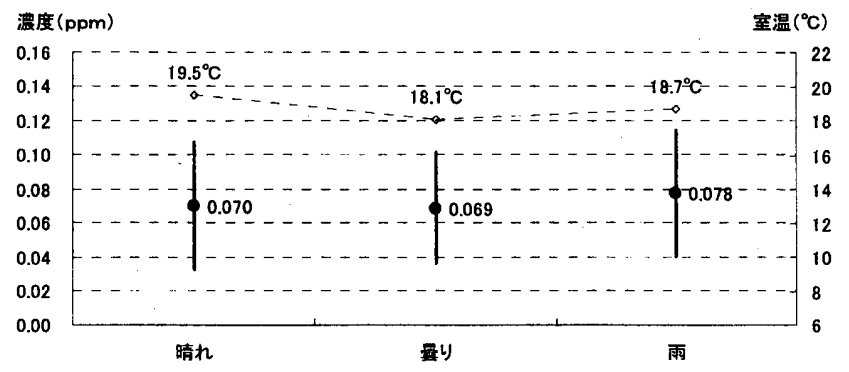

図17＼cjkstart測定日の天候とホルムアルデヒド濃度

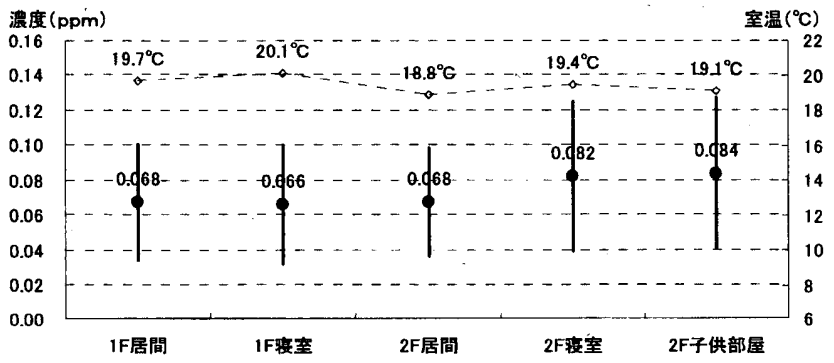

図18 測定室の階数及び用途とホルムアルデヒド濃度（一戸建て住宅）

\section{4.まとめ}

本報告では，近年急速に変わりつつあるわが国の住宅における室 内空気環境の現状を把握するため, 約 5000 軒 (有効サンプル数4368) を对象に大規模な実態調査を実施し，以下のような知見を得た。

1） 4 物質（ホルムアルデヒド, トルエン，キシレン，エチルベン ゼン)の平均濃度と厚生労㗢省指針值を超過した住宅数の割合は, $0.071 \mathrm{ppm}(27.3 \%), 0.038 \mathrm{ppm}(12.3 \%), 0.005 \mathrm{ppm}(0.013 \%)$, $0.008 \mathrm{ppm}(0 \%)$ であった。

2 ) 室内ホルムアルデヒド濃度と最も明らかな関係が認められる要 因は室温で，「 $10^{\circ} \mathrm{C}$ 未満」と答之た住宅（77軒）の平均濃度 0.049

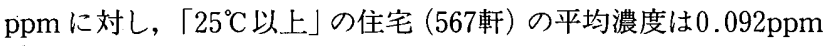
であり，室温が高いと濃度が高い傾向があった。

3 ) 室内ホルムアルデヒド濃度と築後年数との関係は，平成 8 年建 設にピークを有する山型の濃度分布であった。平成 9 年 7 月の厚 生省によるホルムアルデヒド指針值公表とそれに対する住宅供給 者の努力などの影響であろうと推定される。

4）上階ほどホルムアルデヒド濃度が高い傾向が見られた。空間が 一体化していて上階への気流上昇などにより説明可能な戸建てに 対し, 各階が独立な集合住宅における濃度差の原因についてはさ らに検討を要する。

5 ） 24 時間連続換気設備の有無によるホルムアルデヒド平均濃度の 差は明らかではなかった。一方，この換気設備を運転した場合と しない場合との差は約10\%程度であった。

6）体調変化があったと答えたグループ（651軒）となかったと答え たグループ (3682軒) のホルムアルデヒド平均濃度はそれぞれ， $0.077 \mathrm{ppm}$ と $0.071 \mathrm{ppm}$ で，0.13ppm を超えるあたりから体調変 化を訴える割合が増加している。また，濃度はほぼ同じ水準にあ るにもかかわらず，体調変化有の比率に，建て方（一戸建て/共同 建て）による差が認められたが，原因は明らかでない。

7 ）地域別では，ホルムアルデヒド濃度は沖縄に次いで北海道が高 かったが，この主な原因は室温にあると考えられる。

また，本研究では13年度以降も調查を予定しており，以下の点を 踏まえて検討を継続する。

1) 平成12年度調查で濃度の高かった事例を対象に追跡調查を行 い，原因解明と対策立案への資料とする。

2 ) 室温・湿度の影響を明確にするため，把握方法の改善を行う。

3 ) 室内家具・リフォーム・体調変化などに関するアンケート方法 を吟味し，資料を整備する。

4) トルエン等の污染実態に関する資料を蓄積し，形成要因に関す る検討を行う。

\section{謝辞}

本研究は, 国土交通省, 経済産業省, 農林水産省, 厚生労働省, 林野庁と民間団体が組織した「室内空気对策研究会・実態調査分科 会」の平成 12 年度研究の一環として行った。工学院大学名誉教授今 泉勝吉委員長はじめ委員の方々に謝意を表します。また, 調查実施 に協力頂きました住宅都市基盤整備公団及び都道府県の住宅関連部 局の担当各位，县住宅リフォーム・紛争処理支援センタ一の担当各 位，測定に参加いただいた全国の居住者の方々に謝意を表します。 
表 3 各水準のサンプル数と $\mathrm{P}$ 值

\begin{tabular}{|c|c|c|c|c|c|c|c|}
\hline & & & 水準のサ & ナンプル & & & P値 \\
\hline 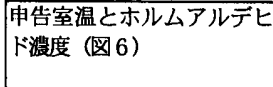 & $5-10^{\circ} \mathrm{C}$ & $10-15^{\circ}$ & $\mid 15-20^{\circ} \mathrm{C}$ & $20-25^{\circ} \mathrm{C}$ & $\begin{array}{c}25 \mathrm{C} \text { 以 } \\
\text { 上 }\end{array}$ & & $<000$ \\
\hline & 77 & 482 & 1367 & 1731 & 567 & & \\
\hline $\begin{array}{l}\text { 筑後年数とホルムアルデ } \\
\text { 卜浱度 (図7) }\end{array}$ & $\begin{array}{l}\text { 箖後 } 1 \text { 年 } \\
\text { 以内内 }\end{array}$ & $\begin{array}{r}\text { 築後 } 2 \\
3 \text { 年 }\end{array}$ & $\begin{array}{c}\text { 築後 } \\
4 \cdot 5 \text { 年 }\end{array}$ & \begin{tabular}{|c|} 
築後 \\
$6 \sim$ \\
10 年 \\
\end{tabular} & \begin{tabular}{|l|} 
筑後 \\
10 年 \\
以上
\end{tabular} & & $<0$ \\
\hline & 2815 & 710 & 199 & 146 & 282 & & \\
\hline $\begin{array}{l}\text { 笑後年数別申告室温別の木 } \\
\text { ルムアルテヒド湍度 (図 8) }\end{array}$ & & $\begin{array}{l}1 \text { 年 } \\
\text { 以内 } \\
\end{array}$ & $2 \cdot 3$ 年 & $4 \cdot 5$ 年 & $\begin{array}{c}6 \sim 10 \\
\text { 年 } \\
\end{array}$ & $\begin{array}{c}10 \text { 年以 } \\
\text { 上 }\end{array}$ & \\
\hline & $10-15^{\circ} \mathrm{C}$ & 221 & 75 & 25 & 37 & 68 & 0.005 \\
\hline & $15-20^{\circ} \mathrm{C}$ & 781 & 236 & 75 & 60 & 114 & $<00$ \\
\hline & $20-25^{\circ} \mathrm{C}$ & 1195 & 272 & 75 & 34 & 58 & $<000$ \\
\hline $\begin{array}{l}\text { 階数とホルムアルデヒド浀 } \\
\text { 度 [一戸建ての場合] (図 9) }\end{array}$ & 1 階 & 2 階 & 3階 & & & & $<000$ \\
\hline & 1956 & 1005 & 63 & & & & \\
\hline 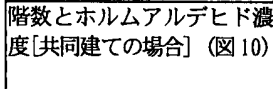 & １階 & 2 階 & 3〜 階 & \begin{tabular}{|c|}
$6 \sim 10$ \\
階 \\
\end{tabular} & $\begin{array}{c}11 \text { 階以 } \\
\text { 上 }\end{array}$ & & $<0001$ \\
\hline & 261 & 232 & 380 & 173 & 100 & & \\
\hline 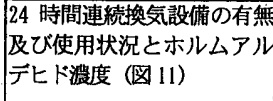 & 24 換气無 & 迶一運輬 & 目有一停止 & & & & 0.1156 \\
\hline & 3212 & 901 & 159 & & & & \\
\hline $\begin{array}{l}24 \text { 時間連続換気設備を有す } \\
\text { る埸合 }\end{array}$ & & 有一運輷 & 侑一停止 & & & & 0.03 \\
\hline & & 901 & 159 & & & & \\
\hline $\begin{array}{l}\text { 空の閏放状況とホルムアル } \\
\text { テヒド浱度 (図 12) }\end{array}$ & & 空開斿 & 埪開放 & 空開放 & 焧開放 & & \\
\hline & 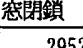 & 1 以下 & $1-3 h$ & $3-5 \mathrm{~h}$ & 5 以上 & & $<0001$ \\
\hline $\begin{array}{l}\text { 㡷調変化の申告とホルムア } \\
\text { ルテテヒド澧度 (図 13) }\end{array}$ & 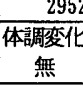 & \begin{tabular}{|l}
72 \\
体調変 \\
化有 \\
\end{tabular} & 297] & 89 & & & 0.000 \\
\hline & 3682 & 651 & & & & & \\
\hline \begin{tabular}{|l} 
地域別のホルムアルデヒド \\
源度 (図 16)
\end{tabular} & I & II & III & IV & $\mathrm{V}$ & VI & $<000$ \\
\hline & 94 & 218 & 1116 & 2863 & 116 & 56 & \\
\hline 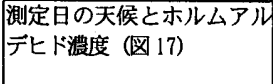 & 晴れ & 盡り & 雨 & & & & 0.003 \\
\hline & 1696 & 810 & 265 & & & & \\
\hline $\begin{array}{l}\text { 測定室の用途とホルムアル } \\
\text { デヒド漕度 (図 18) }\end{array}$ & $1 \mathrm{~F}$ 居間 & 1 F寝室 & $2 \mathrm{~F}$ 間 & \begin{tabular}{|l}
$\mathrm{F}$ 子橵 \\
部屋 \\
\end{tabular} & $2 \mathrm{~F}$ 寝室 & & 000 \\
\hline & 1725 & 134 & 272 & 228 & 454 & & \\
\hline
\end{tabular}

付 1)

住宅金融公庫平成 12 年度 $(2000$ 年度)物件個人住宅規模規格等調查に上れば, その $63.26 \%$ が省エネルギー住宅工事仕㥞に適合し, 前年比 $3.32 \%$ 增であった。

\section{参考文献}

1) Krause, Mailahn, Nagel, Seifert, "Occurrence of Volatile Organic, Compounds in the Air of 500 Homes in the Federal Republic of Germany", The 4th Int. Con. on Indoor Air Quality and Climate, Berlin (West), Vol. 1, pp102-105, 1987

2) Eton, Fallen, Tan, "Investigation of VOCs in Canadian Residences", The 6th Int. Con. on Indoor Air Quality and Climate, Helsinki, Vol. 2, pp141-146, 1993

3) Wallace, Clayton, "Volatile Organic Compounds in 600 U.S. homes: Major Sources of Personal Exposure", The 4th Int. Conf. on Indoor Air Quality and Climate, Berlin (West), Vol. 1, pp183-186, 1987

4）熊谷一清, 池田耕一, 堀 雅宏, 松村年郎, 野嵪淳夫, 木村 洋, 飯倉一 雄, 吉澤. 晋, 居住状態における住宅室内の揮発性有機化合物に関する実 態調查, 日本建築学会計画䒺論文集 No. 522 pp45-52 1999.8

5）熊谷一清, 赤林伸一, 坂口 淳, 山口 - , 渡辺 澄, 池田耕一, 住宅に おける室内化学物質污染の実態に関する研究その 3 ホルムアルデヒド 濃度の実態調查, 日本建築学会大会梗概集 1999年, D-2分冊, pp767-768

6) Kuwasawa, Osawa, Bogaki, Yoshino, "Development of Technology Contributing to a Wholesome Residential Environment", The 5th Canada-Japan Housing R\&D Workshop, pp107-113, 1999 •

7）中川, 大澤, 桑沢, 坊垣, 吉野, 太田, “健康的な居住環境形成技術の開 発 第 4 報 室内空気質（ホルムアルデヒド）調查結果”, 健康学会大会 梗概集 D2，41363，pp735-736，2000.9

8）桑沢, 大澤, 中川, 坊垣, 吉野, “健康的な居住環境形成技術の開発 第 5 報 室内空気質調查結果の VOC 濃度に関する検討”, 建築学会大会梗 概集 D2，41364，pp737-738，2000.9

9）山口 一, 赤林伸一，坂口 淳，木造独立住宅を対象とした居住者意識と 室内化学物質濃度・シェルター性能に関する実態調査 住宅における室内 化学物質污染に関する調査研究 その 1 , 日本建築学会計画系論文集 No. $554 \quad$ pp15-20 2002.4

10）吉野 博 他 7 名, “シックハウスにおける化学物質による室内空気污染 と居住者の健康状況に関する実態調查”，建築学会技術報告集，第15号， pp161-164, 2002.6

11）池田耕一, 朴 俊 錫, 塩津弥佳, 化学物質による室内空気污染データベー スシステムの設計に関する研究，日本建築学会計画系論文集 No. 552 pp49-54 2002:2

12）池田耕一，朴 俊 錫，住宅に扔ける化学物質污染に関する実測調查，その 3 居住空間に拈ける化学物質污染負荷特性, 日本建築学会大会学術講演 梗概集 D-2，pp.909-910，2001

13）朴 俊 錫, 池田耕一, 住宅に扔ける化学物質污染に関する実測調查, その 4 居住空間における化学物質空気污染の追跡調查, 日本建築学会大会学 術講演梗概集 D-2, pp.913-914，2002

14）坊垣和明，ホルムアルデヒド簡易測定器の特性把握実験，空気調和・衛生 工学会学術講演会講演論文集, pp.669-672, 2001.9

15）シックハウス（室内空気污染）問題に関する検討会（厚生省生活衛生局企 画課生活化学安全对策室)，シックハウス（室内空気污染）問題に関する 検討会中間報告書, 平成12年12月15日

16）井上明生, ホルムアルデヒド気中濃度のガイドライン对策, 木材工業, Vol. 52, No. 1, 1997

17）澤地, 瀬戸，大澤ら，住宅の換気システムに関する実験的研究（その 1 ～3 ), 空気調和・衛生工学会学術講演会講演論文集, 1994

（2002年 9 月 10 日原稿受理，2003年 1 月 29 日採用決定） 